\title{
IAMJ
}

INTERNATIONAL

AYURVEDIC

MEDICAL JOURNAL

ISSN: 2320-5091

Impact Factor: 6.719

\section{“KERALIYA VISHESHA CHIKITSA WITH SPECIAL REFRENCE TO KAYASEKA”}

\section{$\underline{\text { Gayatri Kabra }}^{1}, \underline{\text { Parvathy G. Nair }}^{2}, \underline{\text { PradeepKumar P P }}^{3}, \underline{\text { D Sudhakar }}^{4}$}

${ }^{1}$ CCPT Student, ${ }^{2}$ Research Officer, ${ }^{3}$ Research Officer, ${ }^{4}$ Director

National Ayurveda Research Institute for Panchakarma, Cheruthuruthy, Thrissur, Kerela, India

Corresponding Author: gayatri.r.kabra333@gmail.com

https://doi.org/10.46607/iamj2109052021

(Published Online: May 2021)

Open Access

(C) International Ayurvedic Medical Journal, India 2021

Article Received: 27/04/2021 - Peer Reviewed: 06/05/2021 - Accepted for Publication: 08/05/2021

Check for updates

\section{ABSTRACT}

Kayaseka is speciality of keraliya Panchakarma which is modified form of Parisheka Sweda. It has both Snehana and Swedana effect. It yields good results in upper motor neuron lesion with spasticity and rigidity. It is indicated in traumatic conditions, musculoskeletal diseases and rejuvenation therapy. It has equivalent effect as that of Abhyantar Snehapana with appropriate selection of oil and proper techniques.

Keyword: Keraliya Panchakarma, Kayaseka, Pizhi chil, Spasticity, Rigidity, Musculoskeletal disease.

\section{INTRODUCTION}

Kayaseka is developed as a speciality in Kerala. It is also known as Dhara, parisheka, Pizhi chil etc. In Malayalam word 'Pizhi chil' means 'to squeeze.' Though it is one of the best keraliya Panchakarma procedure very less information is available for doctors outside Kerala regarding its absolute indications and benefit. In this procedure a cloth dipped in heated Sneha Dravya is squeezed over the patient's body from a specific height (with a strict monitoring of temperature throughout the procedure). Simultaneous massage is sometimes done along with pouring of Sneha to enhance the benefit of treatment. Broadly we can classify it under Parisheka Sweda. It has both Snehana and Swedana effect. It yields good results in UMN lesions with spasticity, rigidity. It is indicated in traumatic conditions, musculoskeletal diseases and for 
rejuvenation. It has equivalent effect as that of Abhyantar Snehapana with appropriate selection of oil and proper techniques.

\section{STANDARD OPERATING PROCEDURE}

A. PURVAKARMA ${ }^{(1)}$

Kayashudhi followed by following steps:-

1. Shiroabhyangham - Before starting Tail Pichu is to be applied over the scalp with suitable oil.
2. Karnapurna with suitable oil and cotton plugs should be placed in both ears.

3. Thalam-Rasandi churna/Amlaki kalka.

4. The rolled cotton cloth has to be tied above the ears around the head at the level of forehead.

5. Abhyangam with suitable oil.

\section{Material and Equipments:}

\begin{tabular}{|l|l|l|}
\hline 1 & Droni & 01 \\
\hline 2 & Pillow & 01 \\
\hline 3 & Cotton cloth $(4 \times 1 / 2$ angula) & 04 \\
\hline 4 & Vessels (5 litre capacity) & 04 \\
\hline 5 & Warm water (for bath) & \\
\hline 6 & Towel to wipe the oil & \\
\hline 7 & Heating arrangement & \\
\hline 8 & Piece of rolled cloth & \\
\hline
\end{tabular}

\section{B. PRADHAN KARMA ${ }^{(2)}$}

The oil for Kayaseka is to be heated by keeping the vessel on a hot water. The piece of cloth is to be dipped in warm oil and is squeezed over body from a height of 12 angula with a uniform stream with thumb facing downwards. Intermediate massage can be done in downward direction. The procedure is done in following seven positions. These positions are to be adjusted according to disease profile of the patient.
1. Sitting

2. Supine

3. Left lateral

4. Prone

5. Right lateral

6. Supine

7. Sitting

\section{DURATION OF PROCEDURE ${ }^{(2)}$}

\begin{tabular}{|l|l|}
\hline Duration & 45 to $60 \mathrm{~min}$ \\
\hline Total days & 7 to 21 days \\
\hline Timing & $7-11$ am or $4-6 \mathrm{pm}$ \\
\hline
\end{tabular}

\section{PASCHAT KARMA ${ }^{(2)}$}

Clean the body with a towel. Thalam should be applied and Gandharva Hastadi Kashayam/Pati Kashayam should be given orally.

\section{DISCUSSION}

Kayaseka is a type Snigdha Parisheka Sweda. Though it's is type of Swedana, it has effect of both Snehana and Swedana therapy. Therefore it is useful in conditions like Pakshaghata where both Snehana \& Swedana are absolute indications. ${ }^{(3)}$ It is Shreshta among Bahya Snehan, relaxing in nature, it helps to control sheeta, Ruksha and Chala Guna of Vata, it gives Sthirata to Asthi-Mansadi Dhatus therefore it is choice of procedures in UMN lesions with spasticity or rigidity. ${ }^{(4)}$

Parisheka and Avagaha are indicated in Pitta Pradhan conditions and specifically useful in traumatic and ligament injury. ${ }^{(5)}$ It helps in fractures, contusion inju- 
ries, traumatic injuries of bones because of its Bhagna Sandhankara and Asthi Stairyakar Property. ${ }^{(6)}$ Apart from Swedana, it has Dhatu Drudakara, Deha, Agni,
Varna, and Ojo Vriddhikar in nature and thus used for rejuvenation.

Table 1: Illustrating examples of use of oil in specific conditions (based on clinical experience): -

\begin{tabular}{|l|l|}
\hline Karpasasthyadi Tailam & UMN spasticity \\
\hline Dhanvantaram Tailam & Traumatic conditions \\
\hline Dhatturadi Tailam & Movement disorders \\
\hline Ksheerbala Tailam & Balavardhana, tremors \\
\hline Murivenna & Fractures \\
\hline Sahacharadi Tailam & Paraesthesia \\
\hline Kottamchukadi Tailam & Painful neuropathy \\
\hline Prabhanjanam Kuzhampu & Remission phase of demyelinating neuropathy \\
\hline
\end{tabular}

It is said that the procedure should cover the entire body except head because Ushna Parisheka in $\mathrm{Ad}$ hakaya increases the bala but Ushna Parisheka of head may lead to loss of hair and Chakshu karma. ${ }^{(7)(8)}$ The ideal size of cloth is the one that can be comfortably handled inside the palm. The rolled cloth should be tied around the forehead to prevent flow of oil into the eyes. Two masseurs are sufficient in currently accepted practice. Duration of procedure varies according to Dosha predominance. In Vata pitta condition upto 2 hour, Vata kapha condition upto 1 hour is sufficient. In diseases like Pakshavadha, Akshepaka, Apatantraka, Aptanaka, Kayaseka can be done twice a day. Ideally, this procedure is to be done till the perspiration start on body, especially at forehead, chest \& armpits. Frequency of Kayaseka depends on the strength of the patient. With good strength, Kayaseka is done either daily or on alternate days. With moderate strength Kayaseka is to be done with a gap of two to three days. With less strength a gap of four to five days is required between the procedures. For Pitta pradhan conditions slightly warm temperature is used. For Vata pradhan and Kapha pradhan, barely hot and a temperature at which sneha melts respectively is required

\section{COMMONLY USED OILS}

Commonly used oils for Kayaseka include Karpasasthyadi Tailam, Dhanvantaram Tailam, Dhatturadi Tailam, Ksheerbala Tailam, Murivenna, Sahacharadi Tailam, Kottamchukadi Tailam And Prabhanjanam Kuzhampu.

\section{E. REUSE OF OIL ${ }^{(9)}$}

It is ideal to use fresh oil everyday but it is not affordable for everyone. Thus, the practice of reusing the oil used on the first day for 2 more days. After that the deficient volume is added each day. On the fourth day fresh oil is used. On seventh day, the two batches of used oils (of $3^{\text {rd }}$ and $6^{\text {th }}$ day) are added together and used.

\section{F. INDICATION}

1. Specific indications include upper motor neuron lesions with spasticity (pyramidal tract lesion) or rigidity (extra pyramidal tract lesion).

2. Stroke with spasticity, hemiplegia, paraplegia.

3. Movement disorders like chorea, tremors, Parkinson's disease.

4. Musculoskeletal diseases like cartilage degeneration, fractures, ligaments injuries, traumatic injuries.

5. Rejuvenation therapy.

G. CONTRAINDICATION

1. Painful inflammatory conditions.

2. Fever.

3. Gastrointestinal problems like diarrhoea, digestive disease.

4. Respiratory disorders with cough, breathing difficulty or pneumonia.

\section{H. COMPLICATION ${ }^{(10)}$}

Complications can occur from pouring of oil from a greater height than advised, with a rapid rate or for prolonged time likewise - 
1. Burning sensation

2. Erysipelas

3. Fatigue

4. Hoarseness of voice

5. Splitting pain in joints

6. Vomiting

7. Fever

8. Urticarial

9. Haemorrhage

10.Urinary and respiratory tract infections.

\section{PATHY APATHYA ${ }^{(11)}$}

Pathyapathya for Kayaseka are similar to that of Snehapana. Pathya like Drava, Ushna, Anabhishyandi, Natisnigdha, Asankaraahar, Ushnodakapachara, Brahmacharya, Kshapasaya. Apathya like Vegavarodha, Ucchvachana, Shoka, Krodha, Hima, Atapa, Pravata, Vyayam, Yana, Rukshanna Sevana.

\section{J. BENEFITS ${ }^{(6)}$}

Kayaseka can help to improve Dhatus like Mansa, Asthi etc. It can also help to increase Vrushata, Agni Varna Ojasa Vrudhi. It brings Sthiratva in Dhatus like Asthi and it increases longevity. It is helpful in Bhagna chikitsa, Shehana and for Vata Shaman.

\section{K. Variants of Kayaseka.}

1. Ekanga Dhara can be done in conditions like Avabahuka, Hanugraha, Vishwachi etc. ${ }^{(4)}$

2. Some easy modifications have been done in Kayaseka. Instead of cloth some physicians use vessels for Dhara but control and regulation of temperature becomes more accurate in conventional method.

\section{Points to Remember ${ }^{(12)}$}

1. Top to bottom massage is to be accompanied throughout and even the sole should get its share of Dhara.

2. Temperature uniformity is to be maintained to avoid complication.

3. Rhythmic and synchronized Dhara and massage should be done.

4. In Akshepaka, Apatantraka, Pakshwadha, Ardita and Apantanka bath should be avoided after Kayaseka.

\section{CONCLUSION}

Kayaseka is a combination of Snehana and Swedana therapy. It is useful in Stambha Pradhan Vata condition due to Sheeta and Ruksha Guna like spasticity and rigidity. It is also useful in movement disorders like chorea and tremors. It is indicated in Bhagnachikitsa and it is Dhatu Stairyakar. Therefore, it is used in traumatic injuries, fracture and ligament injury. It is Dhatu Drudakara, Deha, Agni, Varna, and Ojo Vriddhikar, Vrushya in nature thus preferable in rejuvenation therapy.

\section{REFERENCES}

1. Prof G. S Lavekar, Dr T. V Menon, Dr Bharati et al. practical handbook of Panchakarma procedure by CCRAS 2010 ISBN -978-81-90-7420-9-2, 44.

2. Prof G. S Lavekar, Dr T. V Menon, Dr Bharati et al. practical handbook of Panchakarma procedure by CCRAS 2010 ISBN -978-81-90-7420-9-2, 45.

3. Dr Bhahmanand Tripathi, Dr Prabhakar J Deshpande. Charak samhita chikitsasthan. Chaukhmba surbharti prakashan.2008, 2, 28/100,956.

4. Dr Pavna Jayram, Dr Manoj Sankarnarayan.Keraliya chikitsa paddhatih SMIAE and Charitable trust. ISBN 978-81-922529-8-8, 92.

5. Kaviraj, Dr Ambikadatta Shastri. Sushruta Samhita chikitsasthan.Chaukhmba Sanskrit sansthan, vikram samvat 2074, ISBN -978-81-89798-20-08, 32/14,174.

6. Dr Pavna Jayram, Dr Manoj Sankarnarayan.Keraliya chikitsa paddhatih SMIAE and Charitable trust. ISBN 978-81-922529-8-8, 46.

7. Puthiyedath Raman Menon, Dr M Prasad. Sirassekadi vidhi. September 2009 .page no.43.

8. Prof Ravi Dutta Tripathi. Ashtangahridayam Sutrasthan chaukhmba Sanskrit pratishthan, 2012, 2/17, 34.

9. Puthiyedath Raman Menon, Dr M Prasad. Sirassekadi vidhi. September 2009. page no.46.

10. Vaidya Vasant C Patil.Principles and practice of Panchakarma.chaukhmba publication. $4^{\mathrm{TH}}$ edition 2014.page no.228

11. Prof Ravi Dutta Tripathi. Ashtangahridayam Sutrasthan chaukhmba Sanskrit pratishthan, 2012, 16/2527,247 .

12. Puthiyedath Raman Menon, Dr M Prasad. Sirassekadi vidhi. September 2009. page no.49. 


\section{ANNEXURE}

\section{(ANNEXURE 1.1)}

Material and equipments

\begin{tabular}{|l|l|l|}
\hline 1 & Droni & 01 \\
\hline 2 & Pillow & 01 \\
\hline 4 & Cotton cloth $(4 \times 1 / 2$ angula) & 04 \\
\hline 5 & Vessels (5 litre capacity) & 04 \\
\hline 6 & Warm water (for bath) & \\
\hline 7 & Towel to wipe the oil & \\
\hline 8 & Heating arrangement & \\
\hline
\end{tabular}

\section{(ANNEXURE 1.2)}

\section{Medicated Oil for Abhyangam}

\begin{tabular}{|l|l|l|}
\hline 1 & Medicated oil (3 litre /day) & $5-6$ litre for 7 days \\
\hline 2 & Medicated oil for Abhyangam & $100 \mathrm{ml}$ \\
\hline 3 & Rasnadi Churna for Thalam & $5 \mathrm{Gm}$. \\
\hline
\end{tabular}

\section{(ANNEXURE 1.3)}

Manpower

\begin{tabular}{|l|l|l|}
\hline 1 & Ayurvedic physician & 01 \\
\hline 2 & Masseur & 04 \\
\hline
\end{tabular}

\section{Source of Support: Nil \\ Conflict of Interest: None Declared}

How to cite this URL: Gayatri Kabra Et Al: "Keraliya Vishesha Chikitsa With Special Refrence To Kayaseka. International Ayurvedic Medical Journal \{online\} 2021 \{cited May, 2021\} Available from: http://www.iamj.in/posts/images/upload/1071 1075.pdf 